\title{
MODERNISASI PENDIDIKAN PONDOK PESANTREN AL-GHOZALI BOGOR
}

\author{
Indra Lesmana \\ Lesmana2497@gmail.com \\ Ahmad Haromaini \\ aharomaini@unis.ac.id \\ (Universitas Islam Syekh Yusuf Tangerang) \\ Hatta Raharja \\ hatta.raharja@uinbanten.ac.id \\ (Universitas Islam Negeri Sultan Maulana Hasanuddin Banten)
}

\begin{abstract}
Abstrak
Kemajuan zaman sangat berpengaruh terhadap sistem dan model pendidikan. Perubahan dan pengembangan sistem pendidikan pesantren yang semakin lama semakin terbuka dengan pola dari luar, untuk menjawab tuntutan zaman. Penelitian ini dilakukan dengan tujuan untuk mengetahui dan menjawab permasalahan: Apakah kebijakan Pondok Pesantren Modern al-Ghozali Bogor sesuai dengan kebutuhan pendidikan sekarang dan bagaimana Pondok Pesantren Modern al-Ghozali Bogor. Penulis menganalisis mengenai Pondok Pesantren Modern al-Ghozali. Hasil penelitian yang dilakukan di Pondok Pesantren al-Ghozali Bogor meliputi pengembangan aspek kependidikan dengan memasukkan pelajaran umum di pesantren, memadukan dua sistem pendidikan tradisional dan modern, dan manajemen pesantren. Modernisasi yang dilakukan menjadikan pondok pesantren dapat melahirkan generasi sumber daya manusia yang memadai dalam menyikapi perkembangan zaman.
\end{abstract}

\section{Kata Kunci: Modernisasi, Pesantren, Pesantren Modern Al-Ghozali}

\section{A. Pendahuluan}

Manusia dan pendidikan merupakan dua relasi yang tidak bisa dipisahkan. Perannya sebagai khalifah dan pemakmur di bumi mengharuskannya memiliki bekal untuk mengemban tugas tersebut dan tugas tersebut dapat terpenuhi melalui belajar. ${ }^{1}$ Bahkan Ibnu Miskawaih seperti yang dikutip Ahmad Haromaini menyebutkan manusia dengan tingkat akurasi berpikir dapat diyakini memiliki kesempurnaan menjadi manusia. ${ }^{2}$ Oleh karena itu pendidikan penting bagi manusia.

\footnotetext{
${ }^{1}$ Ahmad Haromaini, Manusia dan Keharusan Mencari Tahu, Jurnal Pelita, Vol. XVIII. No. 2 JuliDesember 2018, h. 193. p-ISSN:1907-5693, h. 193.

${ }^{2}$ Ahmad Haromaini, Mengajar Dengan Kasih sayang, Jurnal Rausyan Fikr, Vol. 15 No. 2
}

Secara etimologis kata pendidikan merupakan term dari kata didik dengan pembubuhan awalan pe dan akhiran an. Kamus Bahasa Indonesia menyebutnya sebagai perbuatan, hal, cara, dan sebagainya yang memiliki kaitan dengan aktifitas mendidik. ${ }^{3}$ Adapun pengertian pendidikan adalah suatu proses pembelajaran pengetahuan, keterampilan, dan kebiasaan sekumpulan manusia yang diwariskan dari satu generesi ke generasi selanjutnya melalui pengajaran, pelatihan, dan penelitian.

\footnotetext{
September 2019, ISSN.1979-0074 e-ISSN.9 772580594187. h.74.

${ }^{3}$ Abudin Nata, Filsafat Pendidikan Islam, (Jakarta: Gaya Media Pratama, 2009), h. 4.
} 
Dunia pendidikan Islam memperkenalkan term pendidikan dengan merepresentasikan dari beberapa istilah, mulai dari at-tarbiyyah dan at-ta'lim. Kedua term ini popular dalam studi dan kajian-kajian pendidikan Islam. Meskipun disepadankan dalam istilah pendidikan, namun kedua istilah tersebut sejatinya memiliki makna tersendiri dan spesifikasi yang tentunya berlainan dengan yang lain. Pemakaian istilah tersebut berpijak pada al-Qur'an dan al-Sunnah selain akan memberikan pemahaman yang luas tentang pengertian pendidikan Islam, secara substansial-filosofis pun akan memberikan gambaran mendalam tentang bagaimana sebenarnya hakikat dari pendidikan Islam. Untuk kebutuhan itulah, berikut ini penjelasan sekilas tentang pengertian kedua istilah Maha Memperbaiki itu. ${ }^{4}$ Pengertian lain menyebutkan bahwa pendidikan merupakan akumulasi pengalaman yang dialami manusia. Karenanya seseorang atau kelompok orang dapat memahami sesuatu yang sebelumnya tidak mereka pahami. ${ }^{5}$

Tradisi pendidikan Islam khas Indonesia dikenal sistem pendidikan pondok pesantren. Term pondok dan pesantren merupakan dua istilah yang menunjukkan satu pengertian. Pesantren menurut pengertian dasarnya adalah tempat belajar para santri, sedangkan pondok berarti rumah atau tempat tinggal sederhana terbuat dari bambu. Di samping itu, kata pondok mungkin berasal dari bahasa Arab funduq yang berarti asrama atau hotel. Di Jawa termasuk Sunda dan Madura umumnya digunakan istilah pondok dan pesantren, sedang di Aceh dikenal dengan istilah dayah atau rangkang

${ }^{4}$ Beni Muhammad Saebani dan Hendra Akhdhiyat, Ilmu Pendidikan Islam, (Bandung: CV. Pustaka Setia, 2012), cet ke-2, h.40.

${ }^{5}$ Ilmu dan Aplikasi Pendidikan, (T.tp.: PT Imtima, 2007), h. 19. atau menuasa, sedangkan di Minangkabau disebut surau. ${ }^{6}$

Pesantren juga dapat dipahami sebagai lembaga pendidikan dan pengajaran agama, umumnya dengan cara nonklasikal, di mana seorang kiai mengajarkan ilmu agama Islam kepada santri-santri berdasarkan kitab-kitab yang ditulis dalam bahasa Arab oleh ulama abad pertengahan, dan para santrinya biasanya tinggal di pondok (asrama) dalam pesantren tersebut. Pesantren merupakan lembaga pendidikan Islam yang tertua di Indonesia. Lembaga ini disinyalir sebagai sistem pendidikan yang lahir dan tumbuh melalui kultur Indonesia yang mengadopsi model pendidikan sebelumnya, yaitu pendidikan Hindu dan Budha sebelum kedatangan Islam. Pondok pesantren sebagai lembaga pendidikan Islam memiliki kekhasan, baik dari segi sistem maupun unsur pendidikan.

Perbedaan dari segi sistem, terlihat dari proses belajar mengajar yang cenderung sederhana. Meskipun harus diakui ada juga pesantren yang memadukan sistem modern pada praktik pembelajarannya. Berdasarkan tujuan pendiriannya, pesantren hadir dilandasi sekurang-kurangnya oleh dua alasan. Pertama, pesantren dibangun untuk memberikan respons terhadap situasi dan kondisi social suatu masyarakat yang telah mengalami keruntuhan sendi-sendi moral. Wujud respons tersebut biasanya melalui transformasi nilai yang ditawarkan (amar, ma'ruf, nahi munkar). Kedua, salah satu tujuan pesantren ialah ialah menyebarluaskan ajaran tentang universitas Islam ke seluruh pelosok nusantara yang berwatak pluralis, baik pada dimensi kepercayaan, budaya, maupun kondisi sosial masyarakat.

${ }^{6}$ Nurcholis Madjid, Bilik-Bilik Pesantren Sebuah Potret Perjalanan, (Jakarta: Paramadina, 1997), h.5 
Di tengah kompetisi sistem pendidikan yang ada, pesantren sebagai lembaga pendidikan tertua yang mesih bertahan hingga kini tentu saja harus sadar bahwa pembenahan pada wilayah keagamaan tidak lagi memadai. Maka dari itu, pesantren harus proaktif memberikan ruang bagi pembenahan dan pembaruan sistem pendidikan pesantren, dengan senantiasa apresiatif sekaligus selektif menyikapi dan merespon perkembangan dan pragmatism budaya.

Pertama, pembaruan metode pembelajaran. Model pembelajaran pesantren pada mulanya popular menggunakan metodik-didaktik dalam bentuk sorogan, bandogan, halaqoh, dan hafalan. Menurut Mastuhu, pembaruan metode pembelajaran mulai terjadi sekitar pada awal abad ke-20 atau tepatnya sekitar tahun 1970-an, dari pola sorogan berubah menjadi sistem klasikal. Tidak hanya itu, beberapa pendidikan keterampilan juga mulai masuk ke dunia pesantren, seperti bertani, beternak, dan kerajinan tangan. Hal ini dimaksudkan untuk mengembangkan wawasan atau orientasi santri dari pandangan hidup yang selalu berpandangan ukhrawi, supaya seimbang dengan perhatian atas perkara duniawi.

Kedua, pembaruan kurikulum. Pada umumnya, materi pembelajaran pesantren lebih mengutamakan pelajaran agama Islam yang bersumber dari kitab-kitab klasik, seperti tauhid, hadis, tafsir, fiqh, dan sejenisnya. Kurukulum didasarkan pada tingkat kemudahan dan kompleksitas kitab-kitab yang dipelajari, mulai dari tingkat awal, menengah, hingga lanjut. Dalam perkembangannya, hampir setiap pesantren telah melakukan pembaruan kurikulum dengan memasukan pendidikan umum pada kurikulum pesantren. Agama

\footnotetext{
${ }^{7}$ Abu Yasid, dkk, Paradigma Baru Pesantren (Yogyakarta: IRCiSoD, 2018), h. 168.
}

sebanyak $30 \%$ dan $70 \%$ berisi pendidikan umum, dan sebagainya.

Ketiga, pembaruan evaluasi. Kemampuan santri biasanya dievaluasi dengan keberhasilannya mengajarkan kitab kepada orang lain. Apabila audiens merasa puas, maka santri yang bersangkutan dinilai telah lulus. Legalisasi kelulusan merupakan restu kiai bahwa santri tersebut diizinkan pindah untuk mempelajari kitab lain yang lebih tinggi tingkatannya, dan boleh mengajarkan kitab yang pembaruan kurikulum, baik yang mengacu pada Departemen Agama maupun Departemen Pendidikan Nasional, jelas telah meninggalkan model evaluasi tersebut. Yaitu, menggunakan ujian resmi dengan memberikan angka-angka kelulusan serta tanda kelulusan, seperti ijazah.

Keempat, pembaruan organisasi/ manajemen. Pada konteks pembaruan manajemen, meskipun peran kiai tetap dipandang pending, tetapi kiai tidak ditempatkan pada posisi penentu kebijakan secara tunggal. Dari sini, kerja dimulai dengan pembagian unit-unit kerja sesuai urutan yang diterapkan pimpinan pesantren. Ini berarti kekuatan kiai telah terdistribusikan. Berangkat dari hal tersebut, terkadang tetap diakui bahwa pola perencanaan pesantren umumnya masih tergolong sederhana. Sering kali program jangka pendek, menengah, dan jangka panjang tampak tumpang tindih. Akibatnya, tingkat pencapaian programprogram yang demikian sulit diukur secara pasti. $^{8}$

Adapun penelitian yang dilakukan dalam penelitian ini adalah modernisasi pendidikan pondok pesantren al-Ghozali Bogor. Yang meliputi pembaruan metode pembelajaran pesantren, pembaruan kurikulum pesantren, pembaruan evaluasi

\footnotetext{
${ }^{8} \mathrm{Abu}$ Yasid, dkk, Paradigma Baru Pesantren, h. 168-170.
} 
pesantren, dan pembaruan organisasi/ managemen pesantren.

\section{B. Pendidikan Pondok Pesantren \\ 1. Pengertian Pondok Pesantren}

Istilah pesantren sesungguhnya berasal dari kata santri, yang mendapat awalan pe dan akhiran an sebagai tempat tinggal para santri dalam menimba ilmu agama. Santri, menurut Prof. John, berasal dari bahasa Tamil, yang berarti guru mengaji. ${ }^{9}$ Berbeda dengan C. C Berg yang menyatakan bahwa kata santri berasal dari istilah shastri yang dalam bahasa India berarti orang-orang yang memahami bukubuku suci agama Hindu. ${ }^{10}$ Istilah shastri sendiri berasal dari kata shastra yang berarti buku-buku suci, buku-buku agama, atau buku-buku tentang ilmu pengetahuan. $^{11}$

Kata santri juga berarti orang yang mendalami pengetahuannya dalam bidang agama Islam. Sebagai bagian penting dari pesantren, santri merupakan sekelompok orang yang memiliki ketekunan dalam mempelajari kajian kitab-kitab kuning (klasik) yang memuat berbagai ilmu agama, seperti fiqh, tasawuf, tafsir, tauhid, hadis, dan sebagainya. Tidak heran apabila santri dianggap sebaga generasi terbaik dalam ilmu agama yang dapat diandalkan untuk melakukan perubahan sosial dalam kehidupan masyarakat.

Selanjutnya, santri juga dipahami sebagai sosok personifikasi yang paling ideal untuk mencapai tujuan bersama

${ }^{9}$ Anthony John, "From Coastal Setlement to Islamic School and City: Islamization in Sumatera, the Malay Peninula and jawa," dalam J. Fox (ed), Indonesia the Making of a Culture (Canberra: R.S.P.S., A.N.U, 1980), h. 176-177.

${ }^{10}$ C.C. Berg, Wither Islam? A Survey of Modern Movement in the Modern World, (London: Tanpa Penerbit, 1932), h. 257.

${ }^{11}$ M. Chatuverdi dan Tiwari, B.N, A Practical Hindu-English Dictionary, (Delhi: Rashtra Printers, 1970), h. 627 dalam membangun usaha-usaha perbaikan bangsa dan agama. ${ }^{12}$ Keberadaan santri diyakini memiiki peran besar dalam mengaplikasikan visi kebangsaan yang berbasis nilai-nilai keislaman, dan menjadi actor intelektual yang menentukan kualitas pembangunan di segala bidang kehidupan.

Secara historis-antropologis, lembaga pendidikan pesantren tidak dapat dipisahkan dari kultur masyarakat Indonesia yang sangat majemuk. Pesantren dari sudut historis-kultural dapat dikatakan sebagai pusat pelatihan dan bimbingan bagi generasi bangsa yang senantiasa mewarnai dinamika kebudayaan masyarakat.

\section{Sejarah Pondok Pesantren}

Pada bagian ini penulis akan menjelaskan sejarah pondok pesantren yang meliputi: sejarah perkembangan pondok pesantren, model-model pendidikan pesantren, dan elemen-elemen pondok pesantren. Pendidikan Islam di Indonesia pada mulanya dilakukan di rumah-rumah, surau, langgar atau masjid. Di tempat itulah, anak-anak dan orang yang baru masuk Islam belajar agama Islam, membaca al-Qur'an, memahami alQur'an dan ilmu agama lainnya. Dalam perkembangannya, keinginan untuk mempelajari dan memperdalam ajaran agama Islam semakin kuat dan mendorong tumbuhnya tempat tertentu yang khusus digunakan untuk belajar. Tempat tersebut berbeda-beda antara satu daerah lain dalam penamaanya, walaupun tujuannya sama. Hal tersebut dikarenakan perbedaan

${ }^{12}$ H. M. Tidjani Djauhari dan M. Idris Jauhari, "Fungsi Pesantren dalam Pembangunan Umat: Upaya Optimalisasi dan Dinamisasi Internal". Makalah disampaikan dalam Seminar Dinamika Pengembangan Pesantren, PP. AsSalafiah Sumur Putih, Pamekasan Madura, tanggal 5 Juni 1994, h. 3. 
budaya antara satu daerah dengan daerah yang lain. ${ }^{13}$

Jika ditelusuri secara lebih mendalam, maka akan ditemukan statemen bahwa pondok pesantren adalah lembaga pendidikan yang di Indonesia yang berasal dari pribumi. ${ }^{14}$ Sebelum membahas lebih jauh mengenai asal usul pesantren, maka terlebih dahulu saya sebagai penulis akan membahas mengenai pendiri pesantren pertama kali. Terdapat pendapat yang mengatakan bahwa asal usul kapan persisnya kemunculan pesantren di Indonesia belum bisa diketahui dengan pasti. Bahkan, peneliti tarekat dan tradisi Islam asal Belanda, Martin Van Bruinessen, menyatakan tidak mengetahui kapan lembaga tersebut muncul untuk pertama kalinya. Namun, memang banyak pihak yang menyebut dengan berpijak pada pendapat sejarawan yang banyak mengamati kondisi masyarakat Jawa, Pigeud dan de Graaf pesantren sudah ada semenjak abad ke-16. ${ }^{15}$

Dari catatan sejarah, lembaga pendidikan pesantren tertua adalah Pesantren Tegalsari di Ponorogo, yang didirikan pada tahun 1724. Namun sekitar seabad kemudian, yakni melalui survei Belanda tahun 1819, tampak sekali bahwa pesantren tumbuh dan berkembang secara sangat pesat, terutama di seluruh pelosok Pulau Jawa. Survei itu melaporkan lembaga pendidikan ini sudah terdapat di Priangan, Pekalongan, Rembang, Kedu, Surabaya, Madiun dan Ponorogo. Melihat data itu Martin Van Bruinessen yakin

\footnotetext{
${ }^{13}$ Nur Efendi, Manajemen Perubahan di Pondok Pesantren, (Yogyakarta: Teras, 2014), cet ke-1, h. 114.

${ }^{14}$ Depag RI, Pondok Pesantren dan Madrasa Diniyah: Pertumbuhan dan Perkembangannya, (Jakarta: Direktorat Jendral Kelembagaan Islam, 2003), h. 7.

${ }^{15}$ Martin Van Bruinessen, Kitab Kuning, Pesantren dan Tarekat, (Yogyakarta: Gading Publishing, 2012), h. 92.
}

bahwa sebelum abad ke-18 atau sebelum beridirinya Pesantren Karang. ${ }^{16}$

Saridjo sebagaimana dikutip Arifin, berpendapat bahwa pondok pesantren tertua di Jawa Timur (sejak masa perubahan) ialah Pondok Pesantren Tebuireng yang didirikan oleh K.H Hasyim Asy'ari. ${ }^{17}$ Pesantren ini adalah pesantren yang paling berpengaruh di Jawa dalam abad ke-20 ${ }^{18}$ dan merupakan kiblatnya pesantren di Jawa dan Madura, meski fakta sejarah menunjukkan bahwa pondok pesantren tertua di Jawa Timur yang ada sampai sekarang ini, yang keberadaanya dicatat dalam Serat Centhini yang ditulis pada abad ke-18 adalah pesantren Sidosermo di Surabaya dan pesantren Telagsari di Ponorogo. ${ }^{19}$

Terlepas dari kapan kemunculannya, pondok pesantren memliki akal tradisi yang sangat kuat di lingkungan masyarakat Indonesia. M. Dawam Rahardjo menyebutkan bahwa pesantren merupakan salah satu symbol budaya pendidikan asli Indonesia (Nusantara). Secara historis sistem pendidikan yang berkembang di pesantren memang berakar pada tradisi pendidikan keagamaan semasa agama Hindu dan Budha yang berkembang di Indonesia. ${ }^{20}$ Islamisasi yang berlangsung sangat intensif di Nusantara sejak awal abad ke XIII telah mentransformasikan

\footnotetext{
${ }^{16}$ Pesantren ini berada di daerah Banten, kirakira di sekitar gunug Karang, sebelah barat Pandeglang.

${ }^{17}$ Arifin, Kepemimpinan Kiai: Kasus Pondok Tebuireng, (Malang: Kalimasahada Press, 1993), h. 21.

${ }^{18}$ Zamakhsyari Dhofier, Tradisi Pesantren: Studi tentang Pandangan Hidup Kiai, (Jakarta: LP3ES, 1994), h. 116.

${ }^{19}$ Harits D. Ali Haji, Dari Majapahit Menuju Pondok Pesantren: Santri-Santri Negarawan Majapahit sebelum Wali Songo dan Babad Pondok Tegalsari, (Tulungagung: Surya Alam Mandiri, 2009).

${ }^{20}$ M. Dawam Rahardjo, Pergulatan Dunia Pesantren: Membangun dari Bawah, (Jakarta: P3M, 1985), H.94.
} 
budaya pendidikan menjadi bentuk pondok pesantren.

Para ahli sejarah berbeda pendapat mengenai siapa pendiri pesantren pertama kali di Indonesia. Sebagian ahli sejarah menyebutkan bahwa Syaikh Malik Ibrahim adalah pendiri pesantren pertama kali di Jawa. $^{21}$ Sementara itu, Said dan Affar, sebagaimana dikutip oleh Mujamil, menyatakan bahwa Sunan Ampel atau Raden Rahmat sebagai pendiri pesantren di Rembang Kuning Surabaya. ${ }^{22}$ Namun, nampaknya penyataan Said dan Affar ini kurang mampu dijadikan konklusi bahwa yang mendirikan pesantren pertama kali itu adalah Raden Rahmat.

Dari pendapat tersebut, penulis lebih memilih pendapat yang menyatakan bahwa pendiri pesantren pertama kali adalah Syaikh Maulana Malik Ibrahim dengan alasan bahwa beliau adalah penyebar Islam pertama kali di Jawa yang melakukan akulturasi kebudayaan dan merupakan peletak dasar pertama berdirinya pesantren.

Dawam Rahadjo mengemukakan bahwa jika benar pesantren telah dirintis oleh Syekh Maulana Malik Ibrahim sebagai penyebar Islam pertama di Jawa, maka bisa dipahami apabila peneliti sejarah dengan cepat mengambil kesimpulan bahwa pesantren adalah suatu model pendidikan yang sama tuanya dengan Islam di Indonesia. ${ }^{23}$

\section{Model-model Pendidikan Pesantren}

Setelah memahami tujuan berdirinya lembaga pendidikan pesantren, saatnya kita

\footnotetext{
${ }^{21}$ Mahmud Yunus, Sejarah Pendidikan Islam di Indonesia, (Jakarta: Hidakarya Agung, 1985), h. 231.

${ }^{22}$ Mujamil Qomar, Pesantren: Dari Transformasi Metodologi menuju Demokratisasi Institusi, (Jakarta: Erlangga, 2005), h. 8.

${ }^{23}$ Sunyoto, "Pesantren dalam Alam Pendidikan Nasional", dalam Dawam Rahadjo (ed), Pesantren dan Pembaharuan, (t.kp: LP3ES, 1995), h. 65 .
}

menganalisis model pendidikan pesantren atau klasifikasi pesantren yang tumbuh berkembang di Indonesia. Secara sederhana, pengklasifikasian model pendidikan pesantren tersebut bukan bermaksud memetakan pesantren yang dianggap paling bagus dan berkualitas, melainkan hanya sebagai gambaran bagi kita untuk mengenal salah satu model pendidikan yang diterapkan di pesantren, antara pesantren tradisional atau salaf dan pesantren modern. Oleh karna itu, penulis akan memperjelas perbedaan keduanya, dan mencoba mengklarifikasi pesantren dalam tiga strata model pendidikan berikut: ${ }^{24}$

Pertama, Pesantren tradisional sering disebut dengan istilah pesantren salaf. Secara substansial, pesantren model ini lebih menitikberatkan pada kajian-kajian terhadap kitab-kitab klasik yang hanya terbatas pada ilmu fiqh, akidah, tata bahasa Arab, akhlak, tasawuf dan sebagainya. Karakteristik model pesantren ini memang bisa dilihat dari sistem pendidikannya, seperti terbatas pada kajian kitab kuning, bahtsul masail, identic dengan memakai kopiah, sarung, dan segala hal tradisional lainnya. Tak ayal, kultur dan paradigma santri dari segi pola berpikirnya terkesan klasik, primitif, dan eksklusif.

Secara umum, pesantren tradisional memiliki beberapa ciri. Pertama, tidak memiliki manajemen dan administrasi modern, serta pengelolaan pesantren berpusat pada aturan yang dibuat kiai. Kedua, terikat kuat dengan figur seorang kiai sebagai tokoh sentral dari setiap kebijakan yang ada di pesantren. Ketiga, pola dan sistem pendidikan bersifat konvensional dan berpijak pada tradisi lama, pengajaran bersifat satu arah, serta santri hanya mendengarkan penjelasan

\footnotetext{
${ }^{24}$ Hamdan Farchan dan Syarifuddin, Titik Tengkar Pesantren: Resolusi Konflik Masyarakat Pesantren, (Yogyakarta: Pilar Media, 2005), h. 1.
} 
kiai. Keempat, bangunan asrama santri tidak tertata rapi, masih menggunakan bangunan kuno atau bangunan kayu. ${ }^{25}$

Kedua, Pesantren modern dikenal juga dengan istilah pesantren khalaf. Ciri khas dari pesantren modern ialah tidak terfokus pada kajian kitab kuning, tetapi juga mengikuti perkembangan zaman dan kemajuan teknologi. Pesantren model ini dalam wujud sistem pendidikannya sudah berbentuk kurikulum yang diorganisir dengan ragam parampingan terhadap nilainilai intrinsik kitab kuning tersebut sehingga bersifat ilmiah yang disertai dengan ilmu-ilmu umum.

Salah satu contoh model pesantren modern ialah Pesantren Modern Darussalam Gontor, dan az-Zaitun Solo. Karakteristik dari model pesantren ini ialah menekankan pada penguasaan bahasa asing, kurikulum berbasis modern, penekanan pada rasionalitas, orientasi masa depan, percaturan hidup yang semakin mengglobal, dan penguasaan terhadap teknologi informasi dan komunikasi.

Pesantren modern setidaknya memiliki empat ciri penting. Pertama, memiliki manajemen dan administrasi modern yang sangat baik. Kedua, tidak terikat pada figur kiai sebagai tokoh dan pimpinan sentral. Ketiga, pola dan sistem pendidikan yang digunakan modern dengan kurikulum tidak hanya tergantung pada ilmu agama, tetapi juga ilmu umum. Keempat, sarana dan prasarana bangunan lebih mapan, tertata rapi, permanen, dan berpagar. Berbagai fasilitas pendidikan yang terdapat dalam pesantren modern menjadi salah satu keunggulan tersendiri yang bisa meningkatkan kualitas sumber daya manusianya. ${ }^{26}$

\begin{tabular}{|c|c|c|}
\hline${ }^{25}$ Mohammad & Takdir, & Modernisasi \\
\hline $\begin{array}{l}{ }^{26} \text { Mohammad } \\
\text { urikulum Pesantren }\end{array}$ & $\begin{array}{l}\text { Takdir, } \\
\text { 1. } 43\end{array}$ & Mode \\
\hline
\end{tabular}

Ketiga, Pesantren semi modern merupakan perpaduan antara pesantren tradisional dan modern. Pesantren model ini bercirikan nilai-nilai tradisional yang masih kental dipegang teguh, kiai masih menempati posisi sentral, dan norma kode etik pesantren masih tetap menjadi standar pola pengembangan pesantren. Tetapi, pesantren juga mengadopsi sistem pendidikan modern yang relevan dengan perkembangan zamandan tantangan masa depan.

Selain pengajaran kitab kuning, model pesantren ini juga masih terus menerus mengembangkan nalar kritis dan keterampilan santri sehingga keberadaannya pun masih beradaptasi dengan lingkungan sekitar dan berkiprah dalam pengembangan sosial kemasyarakatan. ${ }^{27}$ Pesantren yang menerapkan model ini ialah Pesantren Annuqayah (Sumenep), Pesantren Tebuireng (Jombang), dan Pesantren Mathali'ul Falah (Kajen).

\section{Sistem Pembelajaran Pondok Pesantren}

Dalam penyelenggaraannya, pondok pesantren memiliki kekhasan dalam sistem pembelajaran yang diterapkan. Sistem pembelajaran ini kemudian diimplementasikan melalui beberapa metode. Metode-metode tersebut kemudian ada yang menggabungkannya ada yang mengambil kekhasan yang saja.

Metode-metode yang digunakan pondok pesantren ada yang mengkhususkan penggunaan metode disesuaikan dengan nama pondok yang diselenggarakan. Pondok pesantren ada yang menggunakan sistem klasikal namun juga ada yang bersifat universal. Pesantren

\footnotetext{
${ }^{27}$ Suyoto, "Pondok Pesantren dalam Alam Pendidikan Nasional", dalam Dawan Raharjo, Pesantren dan Pembaruan, (Jakarta: LP3ES, 1998), h. 61 .
} 
pada mulanya menggunakan metodemetode tradisional, yaitu metode: ${ }^{28}$ sorogan, wetonan, ceramah, muhawarah, mudzakarah, hifdz, fath al-kutub, dan metode majelis ta'lim. Ragam metode yang dikembangkan pondok pesantren menjadi nilai lebih yang kemudian dapat menjadikannya sebagai lembaga pendidikan Islam yang memiliki kekhasan dan tentunya mengembangkan karakter tertentu. Setiap metode yang diterapkan memiliki kelebihan dan kekurangan, namun demikian keduanya bersinergi saling melengkapi.

\section{Pondok Pesantren Al-Ghozali Bogor 1. Sejarah Berdirinya Pesantren al- Ghozali}

Pondok Pesantren al-Ghozali berdiri di atas lahan seluas 2 ha $7000 \mathrm{~m} 2$ di bawah naungan yayasan pendidikan Islam alGhozali. Beralamatkan di jalan Permata No. 19 Curug Gunugsindur Bogor, dan telah berdiri sejak 11 Januari 1982 telah disahkan akta notaries No 10 tahun 1982. Hingga kini, Pondok Pesantren al-Ghozali menyelenggarakan pendidikan formal mulai dari MI, SMP, hingga SMA, dan telah meluluskan banyak santri yang datang dari berbagai penjuru daerah. Pondok Pesantren ini pertama kali didirikan atas inisiatif K.H. Ghozali, yang kemudian dijadikan nama yayasan dan pondok pesantren. Kini, Yayasan Pendidikan al-Ghozali dipimpin oleh anaknya yang pertama $H$. Drs. Enday Jauhari Firdaus. Berawal dari sebuah masjid dan gedung 2 lantai yang sederhana, bahkan jauh dari kesan mapan.

Atas usulan dari para kolega sesama alumni Pondok Pesantren Modern Darussalam Gontor angkatan 79 yang mengadakan pertemuan dengan $\mathrm{H}$. Enday

\footnotetext{
${ }^{28}$ Kompri, Manajemen dan Kepemimpinan Pondok Pesantren, (Jakarta: Prenadamedia Group, 2018), h. 130-135.
}

sebagai salah satu alumnus angkatan tersebut, serta ide program Pesantren Kilat yang diadakan oleh sejumlah Mahasiswa Universitas Islam Negeri Syarif Hidayatullah Jakarta yang sedang melaksanakan Kuliah Kerja Nyata (KKN) di desa Curug. Maka, H. Enday, yang sedang menjabat sebagai Kepala Desa Curug, berinisiatif untuk mengembangkan ide dan usulan ayahnya dan menyempurnakan ide-ide yang ada untuk membangun Pondok Pesantren setelah meresmikan yayasan yang menanunginnya.

Pondok ini didirikan dengan tujuan mencetak generasi penerus bangsa dengan pendidikan yang berkualitas bedasarkan Iman dan Taqwa (IMTAQ) dan Ilmu Pengetahuan dan Teknologi (IPTEK). "Sedari dulu pondok pesantren adalah lembaga pendidikan yang unggul dan menjadi pilihan terbaik, karena tidak hanya mengedepankan Transfer Knowledge. Di pondok pesantren, setiap hari santri diajarkan selama 24 jam hidup disiplin, mandiri dan taat pada ajaran agama. Di dunia ini banyak orang berilmu tapi sedikit dari mereka yang menjalankan nilai-nilai dan ajaran agama, sehingga tidak heran banyak terjadi kejahatan yang dilakukan oleh orang-orang pintar itu.

Pondok pesantrenlah harapan terakhir bangsa ini untuk membentengi generasi muda sejak dini dengan nilai-nilai dan ajaran agama yang dipraktikkan selama 24 jam penuh", ungkap H. Enday Jauhari. Dengan misi, meningkatkan kualitas keilmuan kesiswaan berdasarkan keilmuan kepada Allah Swt, kemandirian, kreatif serta tanggap terhadap perubahan zaman dan mencetak siswa yang berbudi luhur Rasulullah Saw sebagai panutannya, Pondok Pesantren al-Ghozali menerapkan pendidikan dengan kurikulum yang menggabungkan pendidikan nasional dan pesantren salaf. 
Para santri diajarkan pengetahuan umum sebagaimana siswa di sekolah umum, dan juga pelajaran kitab kuning sebagai landasan pengetahuan agama mereka, seperti kitab fiqih. Inilah yang membedakan Pondok Pesantren al-Ghozali dengan Pondok Pesantren lainnya. Santri pondok pesantren Al-Ghozali Bogor dinilai lebih memiliki intelektual yang sesuai dengan perkembangan zaman dan tidak identikkan dengan kesan kolot dan jauh dari kesan modern.

Pemenuhan modernisasi pondok pesantren al-Ghozali Bogor, pihak pengelola memfasilitasi sarana penunjang aspek kemoderna tersebut mulai dari diselenggarakannya berbagai klub ekstra kulikuler, antara lain: drum band, bela diri, komputer, bola basket, sepak bola, volly, tenis meja, kegiatan bahasa, shymponi Islam, teater, seni baca al-qur'an, marawis, dan jurnalistik (diskusi dan menulis). Semua kegiatan didukung secara maksimal dengan harapan dapat menjadi bekal kemampuan santri di masa yang akan datang. Perlengkapan sarana dan prasarana juga tak luput dari perhatian pihak pondok pesantren.

Dalam masa berkembangnya, pondok menyediakan berbagai sarana dan prasarana yang dapat menunjang kelancaran kegiatan minat bakat dan belajar santri, seperti: sarana olahraga, kantin, laboratorium, asrama putra/putri, taman baca, ruang belajar, perpuskataan, ruang komputer, wartel dan ruang Keterampilan. Untuk memperoleh pengetahuan dan pengembangan bakat secara maksimal, para santri juga diasuh dan diajar oleh para Ustadz yang kompeten. Para Ustadz didatangkan dari alumni Pondok Modern Darussalam Gontor, Pondok Modern Daar el-Qolam, Pondok Modern al-Ghozali dan sekolah umum, serta lulusan Perguruan Tinggi Negeri (UIN) maupun Swasta.
Kegiatan santri dari bangun tidur hingga tidur kembali dipenuhi dengan berbagai kegiatan. Dimulai dengan kegiatan belajar mengajar, kegiatan ekstra kulikuler, pengajian kitab kuning dan muhadlarah (latihan pidato 3 bahasa: Arab, Inggis dan Indonesia). dalam kesehariannya, para santri diwajibkan berbahasa Arab dan Inggris sebagai penunjang keilmuan mereka di masa depan. Semua kegiatan ini diawasi langsung oleh para asatidz (dewan guru) yang dibantu oleh pengurus Organisasi Pelajar Pondok Modern al-Ghozali (OPPMA) dan Organisasi Siswa Intra Sekolah (OSIS) yang terdiri dari para santri tingkat akhir. Sebagai Corong informasi wali santri, masyarakat dan pengetahuan santri akan perkembangan teknologi dan zaman, Pondok Pesantren menerbitkan Buletin bernama Sun News yang terbit setiap bulannya.

Kegiatan jurnalistik ini digawangi oleh tim jurnalis yang terdiri dari para santri dan sebagai bagian dari kegiatan intra pondok. Pondok Pesantren al-Ghozali yang telah berdiri lebih dari 10 tahun, juga sarat akan prestasi yang ditorehkan tinta emas perjuangan para santrinya berkat bimbingan dan asuhan para asatidz. Prestasi tersebut meliputi;

a. Partisapasi dalam program pertukaran budaya yang diselenggarakan Kedutaan Perancis.

b. Penghargaan dari departemen permusiuman, pariwisata dan kebudayaan atas keikutsertaan dalam Festival Teater tingkat SLTA seJABODETABEK.

c. Juara dalam tournament seni bela diri kungfu Naga Mas seJABODETABEK.

d. Juara lomba parade bedug tingkat Kabupaten Bogor.

e. Mewakili Kecamatan Gunungsindur dalam acara gelar senja pramuka tingkat Kabupaten Bogor 
Pondok Pesantren al-Ghozali juga sampai saat ini, telah meluluskan banyak santri mukim maupun non mukim yang berkiprah di masyarakat dengan beragam profesi. Ada yang menjadi ustadz, guru, dokter, aparatur negara aktivis mahasiswa, dan juga aktivis sosial. Hingga saat ini, jumlah santri al-Ghozali sebanyak 500 orang, terdiri dari santri dan masyarakat sekitar yang non mukim. Inilah letak perbedaan lain yang ditawarkan Pondok Pesantren al-Ghozali. Selain mendidik siswa dengan mengikuti perkembangan zaman dan tidak melulu identik dengan ikon sarungan dan kolot.

Pondok pesantren juga membiasakan para santrinya untuk bersosialisasi dengan masyarakat sekitar. Pondok pesantren membuka diri dengan masyarakat sehingga kapanpun masyarakat bisa berinteraksi dengan para santri. Hal ini dilakukan untuk mengantisipasi kekagetan mereka setelah lulus dari pondok untuk beradaptasi dan bersosialisasi dengan masyarakat di sekitarnya. Mereka adalah harapan dan pengabdi masyarakat, sehingga diharuskan cepat beradaptasi dengan lingkungan sekitar.

Oleh karena itu, Pondok Pesantren melatihnya dengan terbiasa berbaur dengan masyarakat, dan melakukan berbagai aktifitas sosial bersama masyarakat, seperti menjaga kebersihan Pondok dan sekitarnya. Itulah ciri khas dan filosofi Pondok pesantren al-Ghozali, Pondok pesantren yang bermasyarakat.

\section{Sistem Pendidikan dan Pengajaran Pondok Pesantren al-Ghozali}

Secara etimologis, istilah "sistem" merupakan hasil adopsi dari kata asing "system" (Bahasa Inggris) atau "systemata" (Bahasa Yunani) dengan arti "suatu kesatuan yang tersusun secara terpadu antara bagian-bagian kelengkapannya dengan memiliki tujuan secara pasti”, atau "seperangkat komponen yang bekerja sama guna mencpai suatu tujuan
tertentu”. 29

Pengertian "sistem" bisa diberikan terhadap suatu perangkat atau mekanisme yang terdiri dari bagian-bagian dimana satu sama lain saling berhubungan dan memperkuat. Dengan demikian sistem adalah suatu sarana yang yang diperlukan untuk mencapai tujuan. Bila digunakan dalam istilah system pendidikan pesantren yaitu sarana yang berupa perangkat organisasi yang diciptakan untuk mencapai tujuan pendidikan yang berlangsung dalam pondok pesantren. ${ }^{30}$

Kata pendidikan secara etimologis merupakan yang memiliki asal dari "didik". Kata ini kemudian berkembang dengan adanya penambahan awalan pen dan akhiran an. Kata tersebut sebagaimana dijelaskan dalam Kamus Umum Bahasa Indonesia adalah (perbuatan, hal, cara, dan sebagainya) mendidik. ${ }^{31}$ Adapun pengertian pendidikan adalah suatu proses pembelajaran pengetahuan, keterampilan, dan kebiasaan sekumpulan manusia yang diwariskan dari satu genereasi ke generasi selanjutnya melalui pengajaran, pelatihan, dan penelitian.

Pesantren sebagai lembaga pendidikan tradisional, pada umumnya tidak memiliki rumusan tujuan pendidikan secara rinci. Pesantren biasanya tidak menjabarkan sebuah sistem pendidikan yang lengkap dan konsisten direncanakan secara terperinci. Namun secara garis besar, tujuan pendidikan pesantren dapat diasumsikan sebagai berikut:

a. Tujuan umum, yaitu untuk membimbing anak didik (santri) untuk menjadi manusia yang berkepribadian

\footnotetext{
${ }^{29}$ I Made Arya Utama, Hukum Lingkungan, (T.pt.: Pustaka Sutra, t.t), h. 125.

${ }^{30}$ M. Arifin, Kapita Selekta Pendidikan Islam dan Umum..., h. 257.

${ }^{31}$ Abudin Nata, Filsafat Pendidikan Islam...,
} 
islami yang sanggup dengan ilmu agamanya menjadi mubaligh Islam dalam masyarakat sekitar melalui ilmu dan amalnya.

b. Tujuan khusus, yaitu mempersiapkan para santri untuk menjadi orang yang alim dalam ilmu agama yang diajarkan oleh kyai yang bersangkutan serta mengamalkanya dalam masyarakat. ${ }^{32}$

Sistem pendidikan pondok pesantren al-Ghozali pada awalnya adalah bersifat non formal. Yaitu hanya pesantren kilat saja yang diadakan oleh sejumlah mahasiswa UIN Ciputat yang sedang melaksanakan KKN (Kuliah Kerja Nyata) di desa Curug. Maka, H. Enday, yang sedang menjabat sebagai Kepala Desa Curug, berinisiatif untuk mengembangkan ide dan usulan ayahnya dan menyempurnakan ide-ide yang ada untuk membangun pondok pesantren.

Untuk kegiatan santri itu sendiri terbagi kedalam beberapa bagian kegiatan. Untuk kegiatannya dibagi oleh Majelis Pengasuhan Santri (MPS). Pembagian ini sesuai dengan tingkat kemampuan santri itu sendiri dalam memahami pelajaran, hal ini bertujuan untuk lebih mengefisiensikan keadaan pembelajaran di dalam kelas.

\section{Metode Pembelajaran Pondok Pesantren al-Ghozali}

Metode merupakan suatu cara atau siasat untuk menyampaikan pelajaran agar santri dapat mengetahui, memahami dan mempergunakannya dengan baik dan benar. Ada empat pendekatan metode yang digunakan oleh Pondok Pesantren alGhozali, yaitu:

\section{a. Hafalan}

Metode ini dipakai agar mempermudah santri dalam mempelajari materi, diantarannya: teks kitab berbahasa

\footnotetext{
${ }^{32}$ M. Arifin, Kapita Selekta Pendidikan Islam dan Umum..., h. 110-111.
}

Arab, teks kitab berbahasa Inggris, dan hafalan al-Qur'an.

1) Muraja'ah (mengulang-ngulang), metode ini dipakai agar santri selalu ingat dengan materi yang telah diajarkan.

2) Ceramah, metode ini diberikan untuk memberikan penjelasan dan pengertian bagi suatu masalah.

3) Diskusi (musyawarah), metode ini dipergunakan untuk memecahkan suatu masalah guna menghidupkan kemampuan berfikir santri serta menyalurkan pendapat. ${ }^{33}$

Secara garis besar metode pembelajaran yang dilaksanakan di Pondok Pesantren al-Ghozali dapat dikelompokkan menjadi beberapa macam diantaranya, yaitu sorogan, wetonan, ceramah, muhâwaroh, mudzakaroh, hafalan, dan fathul kutûb dimana diantara masingmasing metode mempunyai ciri dan kekhasan tersendiri yaitu:

\section{b. Sorogan}

Metode sorogan ini dikhususkan kepada santri yang baru masuk atau istilah pondok pesantren al-Ghozali "al-Judad" yang berarti anak baru. Biasanya para ustadz di pesantren al-Ghozali mengajarkan santri baru secara individu, yang mana para santri baru bergantian untuk menghadap ustadz. ${ }^{34}$

\section{c. Wetonan}

Metode wetonan atau disebut juga metode bandongan adalah metode pengajaran dengan cara ustadz/kiai membaca, menerjemahkan, menerangkan dan mengulas kitab/buku-buku keislaman dalam bahasa Arab, sedangkan santri mendengarkannya. Mereka memperhatikan kitab/bukunya sendiri dan membuat

\footnotetext{
${ }^{33}$ Mursyid Anwar, Guru Pondok al-Ghozali, Wawancara Pribadi, Bogor: 15 Juni 2019.

${ }^{34}$ Hasil Observasi Penulis dalam Melakukan Penelitian.
} 
catatan-catatan (baik arti maupun keterangan) tentang kata-kata yang dijelaskan oleh ustadz/kiai. ${ }^{35}$

Metode ini pun, di pondok pesantren al-Ghozali sendiri sangat dikenal santri dan mendapat istilah dari para santri dengan sebutan "nyoret" yang mana biasanya para santri membawa kitab kuning dan catatan kecil di waktu yang sudah terjadwal. ${ }^{36}$

\section{d. Ceramah}

Metode ceramah ini merupakan hasil dari metode wetonan dan metode sorogan. Yang semula metode wetonan dan metode sorogan menjadi ciri khas pesantren, pada beberapa pesantren telah diganti dengan metode ceramah sebagai metode pengajaran yang pokok dengan sistem klasik. Namun pada beberapa pesantren ada yang masih menggunakan metode sorogan dan wetonan untuk pelajaran keaagama, sedangkan untuk pelajaran umum menggunakan metode ceramah. 37

Di pondok pesantren al-Ghozali, metode ceramah digunakan pada saat sekolah pondok santri. Metode ini digunakan pada saat mata pelajaran pondok akidah akhlak, fiqih, dan ushul fiqih.

\section{e. Muhâwarah}

Metode muhâwarah adalah metode yang setiap hari dipraktikkan di dalam pondok pesantren al-Ghozali, dari mulai bangun tidur subuh hingga hendak tidur kembali pada malam hari, yang meliputi para santri, asatidz, dan kiai. Santi-santri di pondok pesantren al-Ghozali diwajibkan berbahasa Arab atau berbahasa Inggris setiap harinya, apabila salah seorang santri

\footnotetext{
${ }^{35}$ Kompri, Manajemen dan Kepemimpinan Pondok Pesantren, (Jakarta: Prenadamedia Group, 2008), h. 131. Penelitian.

${ }^{36}$ Hasil Observasi Penulis dalam Melakukan

${ }^{37}$ Kompri, Manajemen dan Kepemimpinan Pondok Pesantren..., h. 131.
}

terdengar bercakap bahasa Indonesia maka santri tersebut akan dikenakan sanksi langsung maupun sanksi tidak langsung.

Sanksi langsung adalah berupa hukuman di tempat, yang mana biasanya seorang santri terdengar langsung bercakap bahasa Indonesia di depan pengurus bagian bahasa, sementara sanksi tidak langsung berupa hukuman bagi santri yang terkena mata-mata temannya yang mendengar ia bercakap bahasa Indonesia. Mata-mata disini bagi kalangan santri disebut juga dengan istilah "Jasus", yang mana seseorang yang sebelumnya bercakap bahasa Indonesia diperintah oleh bagian bahasa untuk mencatat santri lain yang bercakap menggunakan bahasa Indonesia lalu, diumumkan setelah belajar malam dan diberi hukuman setelahnya. 38

\section{f. Mudzakarah}

Metode ini di pondok pesantren alGhozali digunakan pada saat pelajaran tafsir, Bulughul Maram, Tanqihul Qoul, Fathul Qarîb dan masa'il fiqhiyah. Biasanya setelah ustadz menerangkan, santri diperintah untuk berdiskusi guna mengembangkan cara berfikir santri dan jalan keluar untuk memecahkan masalah. Metode ini digunakan pada santri tingkat tinggi khususnya santri akhir guna mempersiapkan kematangan ilmunya di masyarakat kelak.39

\section{g. Hafalan (Tahfiz)}

Metode hafalan di pondok pesantren al-Ghozali diterapkan pada mata pelajaran Jurumiyah, Muthala'ah, Nahwu Sorf, Aqo 'id. Adapun penambahan pada metode hafalan di pondok pesantren al-Ghozali yaitu Tahfidzul Qur'an (hafalan qur'an), yang mana Tahfidzul Qur'an ini menjadi

\footnotetext{
${ }^{38}$ Hasil Observasi Penulis dalam Melakukan Penelitian.

${ }^{39}$ Hasil Observasi Penulis dalam Melakukan Penelitian.
} 
kegiatan santri yang wajib diikuti setiap santri dan diwisudakan setiap tahunya dari mulai 1 juz hingga 30 juz.40

\section{h. Fathul Kutûb}

Fathul kutûb merupakan kegiatan latihan membaca kitab (terutama kitab klasik) yang umunya ditugaskan kepada santri senior kepada santri senior di pondok pesantren. Sebagai suatu metode, fathul kutub bertujuan menguji kemampuan mereka dalam membaca kitab kuning, khususnya setelah mereka berhasil mengerjakan mata pelajaran kaidah bahasa Arab. Metode ini biasanya dikhususkan bagi santri yang akan menyelesaikan pendidikannya di pondok pesantren.41

\section{Penutup}

Sebagai lembaga pendidikan Islam, Pondok Pesantren Al-Ghozali telah melakukan banyak perubahan dalam proses modernisasi pondok pesantren. Moderniasasi tersebut dilakukan dengan mengubah sistem pondok pesantren, metode pembelajaran serta pemenuhan fasilitas sarana dan prasarana pondok pesantren untuk mengembangkan bakat para santri. Mudah-mudahan penelitian yang sederhana ini dapat memberikan kontribusi positif bagi pengembangkan pondok pesantren maupun lembaga pendidikan Islam lain yang tidak berbasis pesantren. Wallahu a'lam.

\footnotetext{
${ }^{40}$ Hasil Observasi Penulis dalam Melakukan Penelitian.

${ }^{41}$ Kompri, Manajemen dan Kepemimpinan Pondok Pesantren..., h. 136.
}

\section{DAFTAR PUSTAKA}

Achmadi, Islam, Sebagai Paradigma Ilmu Pendidikan, (Yogyakarta: Aditia Media, 1992).

Akhdhiyat Hendra, Saebani, B M, Ilmu Pendidikan Islam, (Bandung: CV. Pustaka Setia, 2012).

Arifin, Kepemimpinan Kiai: Kasus Pondok Tebuireng, (Malang: Kalimasahada Press, 1993).

Arifin, Muzayyin. Kapita Selekta Pendidikan Islam dan Umum, (Jakarta: Bumi Aksara, 1991).

Assegaf, A, R. Politik Pendidikan Nasional, (Yogyakarta: Kurnia Kalam, 2005)

Berg, C. C. Wither Islam? A Survey of Modern Movement in the Modern World, (London: Tanpa Penerbit, 1932).

B. N, Tiwani, Chatuverdi, M, A. A Practical Hindu-English Dictionary, (Delhi: Rashtra Printers, 1970).

Depag, RI. Pondok Pesantren dan Madrasa Diniyah: Pertumbuhan dan Perkembangannya, (Jakarta: Direktorat Jendral Kelembagaan Islam, 2003).

Dhofier, Zamakhsyari. Tradisi Pesantren: Studi tentang Pandangan Hidup Kiai, (Jakarta: LP3ES, 1994).

Drajat, Zakiah. Ilmu Pendidikan Islam, (Jakarta: Bumi Aksara, 1992).

Efendi, Nur. Manajemen Perubahan di Pondok Pesantren, (Yogyakarta: Teras, 2014).

Hawi, Akmal. Kompetensi Guru Pendidikan Agama Islam, (Raja Grafindo Persada, 2013).

Haromaini, Ahmad, Manusia dan Keharusan Mencari Tahu, Jurnal Pelita, Vol. XVIII. No. 2 JuliDesember 2018, h. 193. pISSN:1907-5693.

Haromaini, Ahmad, Mengajar Dengan Kasih sayang, Jurnal Rausyan Fikr, 
Vol. 15 No. 2 September 2019, ISSN.1979-0074 e-ISSN.9 772580594187.

John, Anthony. Indonesia the Making of a Culture (Canberra: R.S.P.S., A.N.U, 1980)

Kompri, Manajemen dan Kepemimpinan Pondok Pesantren, (Jakarta: Prenadamedia Group, 2018)

Kompri, Manajemen dan Kepemimpinan Pondok Pesantren, (Jakarta: Prenadamedia Group, 2018).

Madjid, Nurcholis. Bilik-Bilik Pesantren Sebuah Potret Perjalanan, (Jakarta: Paramadina, 1997).

Makin, Baharudin. Pendidikan Humanistik, (Jogyakarta: Ar-Ruzz Media, 2017)

Martin Van Bruinessen, Kitab Kuning, Pesantren dan Tarekat, (Yogyakarta: Gading Publishing, 2012).

Nata, Abudin. Filsafat Pendidikan Islam, (Jakarta: Gaya Media Pratama, 2009)

Qomar, Mujamil. Pesantren: Dari Transformasi Metodologi mеnијu
Demokratisasi Institusi, (Jakarta: Erlangga, 2005).

Rahardjo, Dawam. Pergulatan Dunia Pesantren: Membangun dari Bawah, (Jakarta: P3M, 1985).

Syarifuddin, Farchan Hamdan. Titik Tengkar Pesantren: Resolusi Konflik Masyarakat Pesantren, (Yogyakarta: Pilar Media, 2005).

Takdir, Mohammad. Modernisasi Kurikulum Pesantren, (Yogyakarta: IRCiSoD, 2018)

Utama, Arya, M, I. Hukum Lingkungan, (T.pt.: Pustaka Sutra, t.t).

Yasid, Abu. Paradigma Baru Pesantren (Yogyakarta: IRCiSoD, 2018).

Yunus, Mahmud. Sejarah Pendidikan Islam di Indonesia, (Jakarta: Hidakarya Agung, 1985).

Zamakhsyari Dhofier, Zamakhsyari. Tradisi Pesantren: Studi tentang Pandangan Hidup Kiai, (Jakarta: LP3ES, 1994). 
